\title{
Suitable Protein and Lipid Levels in Diet for Fingerlings of Red Sea Bream Pagrus major
}

\author{
Toshio Takeuchi, ${ }^{* 1}$ Yasuhiko Shiina, ${ }^{* 1,2}$ and Takeshi Watanabe*1 \\ (Received May 22, 1990)
}

\begin{abstract}
Two feeding experiments were conducted to determine the suitable dietary protein and lipid levels for fingerlings of red sea bream by feeding them with various white fish meal-casein diets containing different levels of protein (CP: 37-52\%) and lipid (CL: 5-20\%).

In Experiment $\mathrm{I}$, the growth rate and feed efficiency increased with increasing $\mathrm{CP}$ content in diet, both values reaching a maximum at the diet level of $52 \%$. In Experiment II, the growth rate and feed efficiency were higher for diets containing $52 \% \mathrm{CP}$, compared to $42 \% \mathrm{CP}$ groups, irrespective of the lipid levels. On the other hand, with an increase in the amount of dietary n3HUFA, the values for growth rate, feed efficiency, and protein efficiency ratio increased, recording high in diets combining $52 \% \mathrm{CP}$ with 15 and $20 \%$ lipids.

This result indicated that the growth of red sea bream fingerlings was influenced by not only dietary protein and lipid levels but also n-3HUFA contents in diet. It is also suggested that the suitable $\mathrm{CP}$ and $\mathrm{CL}$ levels in diet for red sea bream fingerlings may be around $52 \%$ and $15 \%$, respectively.
\end{abstract}

Of late, the net cage culture of red sea bream has been replacing that of yellowtail. The figerlings of red sea bream are generally fed raw fish such as minced sardine, while dry pellets are in limited use. However, pollution with raw fish has become a serious problem. Since the feed type of the fry and fingerlings will have profound impact on their preferences in the later periods, there is an urgent need to develop dry pellets for them.

The nutritıonal requirements of red sea bream have already been worked out. Yone et al. has published a series of papers, ${ }^{1-3)}$ wherein they have concluded that the optimum content of protein and lipid in a diet should be 55 and $10 \%$, respectively.2,3) However, these studies were conducted with semi-purified moist pellet (MP; water content $\geqq 30 \%$ ) and it might be inappropriate to apply their results directly for dry pellet manufacture. Furthermore, only limited knowledge is available concerning the nutritional requirements of the fingerlings. More information should be gathered to develop a dry feed for fingerlings of red sea bream.

This experiment was conducted to determine the suitable dietary protein and lipid levels for fingerl- ings of red sea bream by feeding them with various white fish meal-casein diets containing different levels of protein $(37-52 \%)$ and lipid $(5-20 \%)$.

\section{Materials and Methods}

\section{Experimental Condition}

Two feeding experments were conducted in the Aquaculture Research Laboratory, Nagasaki Prefectural Institute of Fisheries. Before starting the experiments, red sea bream Pagrus major fingerlings were fed for two weeks on minced fish and a commercial red sea bream diet in Expt. I and the commercial diet alone in Expt. II. Then, the fingerlings were randomly divided into four groups of 50 fish each in Expt. I (initial average weight: $1.6 \mathrm{~g}$ ) and into eleven groups of $30 \mathrm{fish}$ each in Expt. II (initial average weight: $7.5 \mathrm{~g}$ ). Fish were fed five times a day in Expt. I and four times a day in Expt. II, each time to satiation. Each group of fish was held in a $100 \mathrm{l}$ tank with areation $(1.0-1.5 \mathrm{l} / \mathrm{min})$, and sea water was supplied at a rate of $2.0-2.5 \mathrm{l} / \mathrm{min}$. Fish were fed experimental diets for 35 days in Expt. I and for 42 days in Expt. II. The water temperature

*1 Department of Aquatic Biosciences, Tokyo University of Fisheries, Konan, Minato, Tokyo 108, Japan (竹内俊郎, 椎名康彦, 渡边 武: 柬京水産大学資源育成学科).

*2 Present address: Taiyo Central R \& D Institute, Taiyo Fishery Co. Ltd., Wadai, Tsukuba, Ibaraki 30042, Japan (大洋㴔業株式会社大洋研究所). 
ranged from 23 to $27^{\circ} \mathrm{C}$ in Expt. I and 22 to $26^{\circ} \mathrm{C}$ in Expt. II.

\section{Experimental Diets}

The composition of the experimental diets used in Expts. I and II are shown in Tables 1 and 2 , respectively. In both experiments, white fish meal containing $65 \%$ crude protein (CP) and vitamin free casein were used as the main protein sources. $\alpha$-Starch was the carbohydrate source and pollock liver oil and beef tallow (Riken Vitamin Co. Ltd.) were the lipid sources. The melting point of beef tallow was below $40^{\circ} \mathrm{C}$. In order to adjust the level of n-3 highly unsaturated fatty acids (n-3HUFA) in diet, Ester 85 (purity of n-3HUFA: $85 \%$ ) obtained from Oriental Yeast Co. Ltd. was used in Expt. I. Experiment I: Diets 1 to 3 were arranged at low-, medium- and high-protein levels containing 37,45 and $52 \% \mathrm{CP}$. The contents of crude lipid (CL) and n-3HUFA in diets 1 to 3 were $15 \%$ and $3 \%$ respectively. Diet 4 had a low lipid level $(10 \% \mathrm{CL})$ with $3 \% \mathrm{n}-3$ HUFA.
Table 1. Composition of the experimental diets for red sea bream in Expt. I $(\%)$

\begin{tabular}{|c|c|c|c|c|}
\hline \multirow{2}{*}{ Ingredient } & \multicolumn{4}{|c|}{ Diet no. } \\
\hline & 1 & 2 & 3 & 4 \\
\hline $\mathrm{CP}$ & 37 & 45 & 52 & 52 \\
\hline $\mathrm{CL}$ & 15 & 15 & 15 & 10 \\
\hline $\mathrm{n}$-3HUFA in diet & 3.0 & 3.0 & 3.0 & 3.0 \\
\hline White fish meal & 55 & 67 & 57 & 57 \\
\hline Casein & 0 & 0 & 15 & 15 \\
\hline$\alpha-\operatorname{Starch}$ & 10 & 10 & 5 & 10 \\
\hline Mineral mix.4) & 5 & 5 & 5 & 5 \\
\hline Vitamin mix."3 & 2 & 2 & 2 & 2 \\
\hline Choline chloride & 0.9 & 0.9 & 0.9 & 0.9 \\
\hline Vitamin E $(50 \%)$ & 0.1 & 0.1 & 0.1 & 0.1 \\
\hline Cellulose & 17 & 6 & 5 & 5 \\
\hline Pollock liver oil & 10 & 9 & 10 & 0 \\
\hline Beef tallow & 0 & 0 & 0 & 2.6 \\
\hline \multirow[t]{2}{*}{ Ester 85* } & 0 & 0 & 0 & 2.4 \\
\hline & \multicolumn{4}{|c|}{ Analytical result } \\
\hline Crude protein & 38.3 & 46.9 & 53.0 & 53.4 \\
\hline Crude lipid & 16.1 & 15.3 & 15.9 & 10.7 \\
\hline n-3HUFA in diet & 3.0 & 3.1 & 3.1 & 3.2 \\
\hline
\end{tabular}

Table 2. Composition of the experimental diets*1 for red sea bream in Expt. II (\%)

\begin{tabular}{|c|c|c|c|c|c|c|c|c|c|c|c|}
\hline \multirow{2}{*}{ Ingredient } & \multicolumn{11}{|c|}{ Diet no } \\
\hline & 1 & 2 & 3 & 4 & 5 & 6 & 7 & 8 & 9 & 10 & 11. \\
\hline $\mathrm{CP}$ & 42 & 42 & 42 & 42 & 52 & 52 & 52 & 52 & 52 & 52 & 52 \\
\hline $\mathrm{CL}$ & 5 & 10 & 15 & 20 & 5 & 10 & 15 & 15 & 20 & 20 & 20 \\
\hline n-3HUFA in diet & 1.0 & 2.2 & 2.2 & 2.2 & 1.2 & 2.2 & 2.2 & 3.2 & 2.2 & 3.2 & 4.2 \\
\hline White fish meal & 46 & 46 & 46 & 46 & 57 & 57 & 57 & 57 & 57 & 57 & 57 \\
\hline Casein & 12 & 12 & 12 & 12 & 15 & 15 & 15 & 15 & 15 & 15 & 15 \\
\hline$\alpha$-Starch & 18 & 18 & 18 & 18 & 10 & 10 & 10 & 10 & 5 & 5 & 5 \\
\hline Mineral mix. ${ }^{* 3}$ & 5 & 5 & 5 & 5 & 5 & 5 & 5 & 5 & 5 & 5 & 5 \\
\hline Vitamin mix. & 2 & 2 & 2 & 2 & 2 & 2 & 2 & 2 & 2 & 2 & 2 \\
\hline Choline chloride & 0.9 & 0.9 & 0.9 & 0.9 & 0.9 & 0.9 & 0.9 & 0.9 & 0.9 & 0.9 & 0.9 \\
\hline Vitamin E $(50 \%)$ & 0.1 & 0.1 & 0.1 & 0.1 & 0.1 & 0.1 & 0.1 & 0.1 & 0.1 & 0.1 & 0.1 \\
\hline Cellulose & 15.6 & 10.6 & 5.6 & 0.6 & 10 & 5 & 0 & 0 & 0 & 0 & 0 \\
\hline Pollock liver oil & 0.4 & 5 & 5 & 5 & 0 & 5 & 5 & 10 & 5 & 10 & 15 \\
\hline \multirow[t]{2}{*}{ Beef tallow } & 0 & 0.4 & 5.4 & 10.4 & 0 & 0 & 5 & 0 & 10 & 5 & 0 \\
\hline & \multicolumn{11}{|c|}{ Analytical resuit } \\
\hline Crude protein & 41.2 & 42.2 & 42.3 & 42.2 & 52.8 & 54.0 & 53.8 & 54.6 & 54.1 & 53.3 & 53.7 \\
\hline Crude lipid & 4.7 & 10.7 & 15.2 & 21.7 & 6.2 & 11.1 & 16.2 & 15.4 & 20.9 & 20.7 & 21.0 \\
\hline Crude starch & 19.2 & 20.0 & 20.3 & 18.0 & 10.0 & 10.0 & 8.5 & 11.5 & 7.0 & 6.8 & 8.2 \\
\hline Moisture & 8.0 & 6.3 & 5.0 & 4.4 & 6.7 & 4.6 & 5.2 & 4.5 & 3.1 & 4.5 & 4.0 \\
\hline $\begin{array}{l}\text { Calorie*: } \\
\quad(\mathrm{kcal} / 100 \mathrm{~g})\end{array}$ & 277 & 332 & 369 & 414 & 315 & 360 & 396 & 401 & 430 & 425 & 433 \\
\hline $\mathrm{C} / \mathbf{P}^{* 3}$ & 67 & 79 & 87 & 98 & 60 & 67 & 74 & 73 & 80 & 80 & 81 \\
\hline$n-3 H U F A$ in diet & 1.1 & 2.1 & 2.0 & 1.8 & 1.6 & 2.2 & 2.1 & 2.7 & 1.8 & 2.9 & 4.0 \\
\hline
\end{tabular}


Table 3. Results of a 35-day feeding trial with red sea bream*1

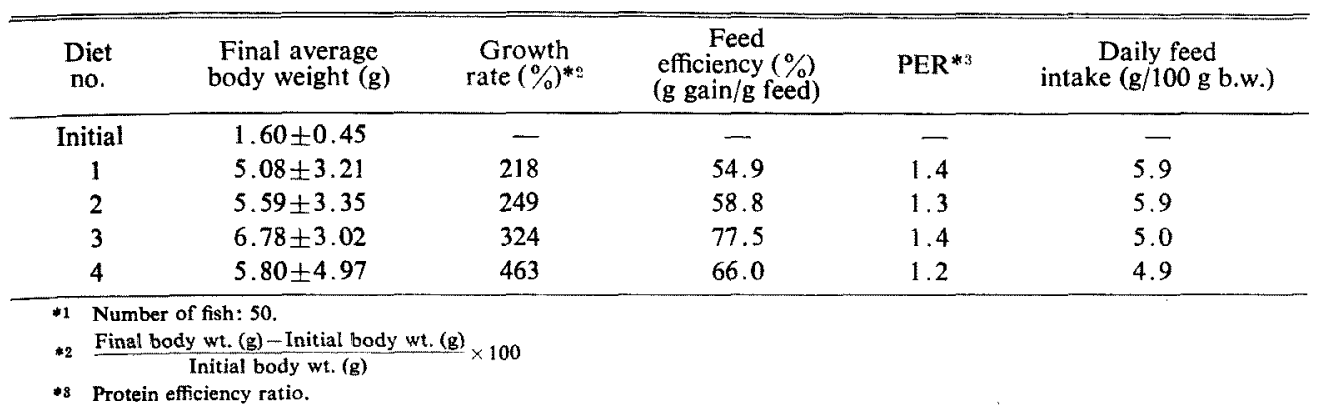

Experiment II: Diets 1 to 4 and diets 5 to 11 were formulated as medium- and high-protein, containing $42 \%$ and $52 \% \mathrm{CP}$ respectively. At both protein levels, the lipid content in diet was elevated from 5 to $20 \%$. Furthermore, n-3HUFA levels were also adjusted to 1 or $1.2 \%$ in $5 \% \mathrm{CL}$ diets and to $2.2 \%$ in $10-20 \% \mathrm{CL}$ diets containing both beef tallow and pollock liver oil. In order to clarify the effect of dietary lipid levels on n3HUFA requirements in diet, high n-3HUFA levels, $3.2 \%$ (diets 8 and 10 ) and $4.2 \%$ (diet 11 ), were incorporated in 15 and $20 \% \mathrm{CL}$ diets. The vitamin and mineral mixtures employed were the same as those described in previous papers. ${ }^{4,53}$ These experimental diets were provided for the fish in a dry pellet form.

\section{Analytical Methods}

The contents of CP, CL and n-3HUFA in the experimental diets were determined by the methods of Kjeldahl, Folch et al. ${ }^{\theta)}$ and GLC analysis, respectively. Crude starch was determined by the procedure of Somogi-Nelson. ${ }^{7)}$ Fatty acids were methyl esterified as described earier. ${ }^{8)}$ The calorie content of diets was calculated using the following values: protein, $4.5 \mathrm{kcal}$; lipid, $8 \mathrm{kcal}$; starch, $2.8 \mathrm{kcal} / \mathrm{g}^{{ }^{\text {) }}}$

Whole body samples obtained from both Expts. $I$ and II were completely homogenized ${ }^{10}$ and subjected to the analytical procedures mentioned above.

\section{Results}

\section{Experiment I}

Results of a 35-day feeding in Expt. I are shown in Table 3. The daily feed intake ranged from 4.9 to $5.9 \%$ among the experimental groups; the highest in diets 1 and 2 containing $37 \%$ and $45 \% \mathrm{CP}$ (analytical value of crude protein is
$38.3 \%$ and $46.9 \%$, respectively). This result agreed with that usually observed that feed intake is high in fish fed low protein diets in order to satisfy the daily requirement of nitrogen. The growth rate and feed efficiency were improved as the dietary protein levels increased, when the lipid level was fixed at $15 \%$, reaching a maximum with the $52 \% \mathrm{CP}$ diet. At the level of $52 \% \mathrm{CP}$ in diets, these values of the fish fed the diet containing $10 \%$ lipid were inferior to those of the fish fed $15 \%$ lipid. The proximate composition of the whole body is shown in Table 4. The final fish, after 35 days of feeding showed low moisture, high protein, lipid and ash in the body, in comparison with the initial fish. The whole body protein of fish fed on diets high in protein levels ( $52 \% \mathrm{CP}$; diets 3 and 4 ) was higher than that on low and medium protein diets $(37 \% \mathrm{CP}, 45 \% \mathrm{CP}$; diets 1 and 2). On the other hand, the whole body lipid was high in fish fed diets 1 and 2 .

\section{Experiment II}

Results of a 42-day feeding in Expt. II are shown in Table 5 and Fig. 1. The daily feed intake did not vary much among the groups, the value ranging from 2.7 to 3.3 . However, the intake recorded in this experiment was lower than in Expt. I, probably due to the size of fish. The growth rate and feed efficiency improved as dietary lipid levels increased, reaching a maximum

Table 4. Proximate composition of the whole bodies of red sea bream in Expt. I (\%)

\begin{tabular}{ccccc}
\hline $\begin{array}{c}\text { Diet } \\
\text { no. }\end{array}$ & $\begin{array}{c}\text { Crude } \\
\text { protein }\end{array}$ & $\begin{array}{c}\text { Crude } \\
\text { lipid }\end{array}$ & $\begin{array}{c}\text { Crude } \\
\text { ash }\end{array}$ & Moisture \\
\hline Initial & 15.4 & 2.4 & 4.2 & 78.8 \\
1 & 16.9 & 8.1 & 4.5 & 72.4 \\
2 & 16.2 & 8.5 & 4.6 & 72.2 \\
3 & 17.7 & 6.2 & 5.1 & 73.6 \\
4 & 18.2 & 7.6 & 5.2 & 71.6 \\
\hline
\end{tabular}




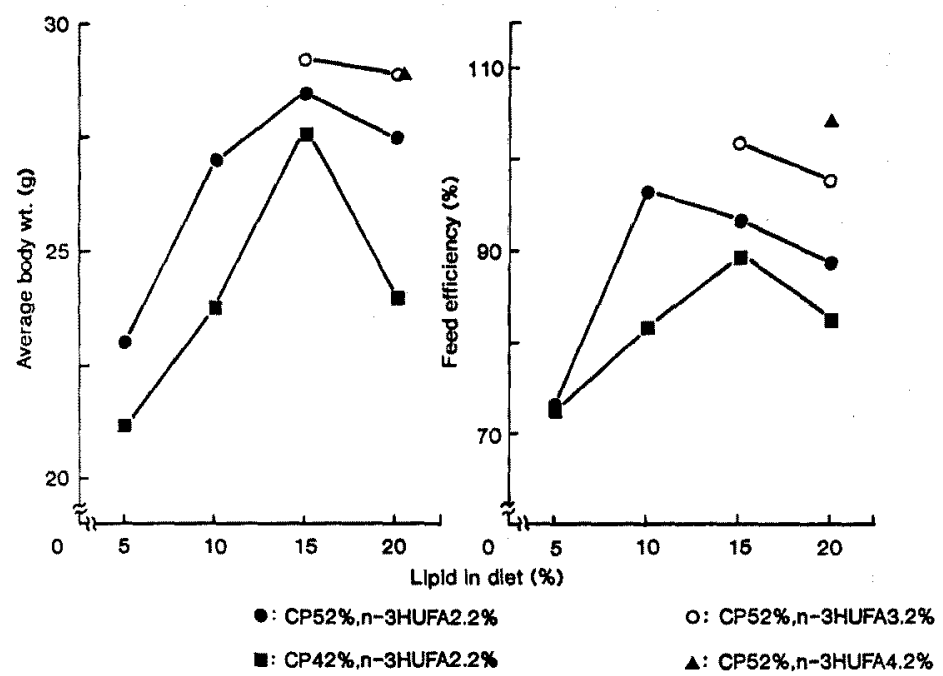

Fig. 1. Effect of dietary protein and lipid levels on growth and feed efficiency of red sea bream.

Table 5. Results of a 42-day feeding trial with red sea bream*1

\begin{tabular}{|c|c|c|c|c|c|c|c|c|c|c|c|}
\hline Diet no. & 1 & 2 & 3 & 4 & 5 & 6 & 7 & 8 & 9 & 10 & 11 \\
\hline $\mathrm{CP}$ & 42 & 42 & 42 & 42 & 52 & 52 & 52 & 52 & 52 & 52 & 52 \\
\hline $\mathrm{CL}$ & 5 & 10 & 15 & 20 & 5 & 10 & 15 & 15 & 20 & 20 & 20 \\
\hline $\mathrm{n}-3$ HUFA in diet & 1.0 & 2.2 & 2.2 & 2.2 & 1.2 & 2.2 & 2.2 & 3.2 & 2.2 & 3.2 & 4.2 \\
\hline \multicolumn{12}{|l|}{ Av. body wt. (g) } \\
\hline Initial & $\begin{array}{r}7.5 \\
\pm 0.9\end{array}$ & $\begin{array}{r}7.5 \\
\pm 1.0\end{array}$ & $\begin{array}{r}7.5 \\
\pm 1.3\end{array}$ & $\begin{array}{r}7.5 \\
\pm 1.1\end{array}$ & $\begin{array}{r}7.5 \\
\pm 1.2\end{array}$ & $\begin{array}{r}7.5 \\
\pm 1.1\end{array}$ & $\begin{array}{r}7.5 \\
+1.2\end{array}$ & $\begin{array}{r}7.5 \\
\pm 1.1\end{array}$ & $\begin{array}{r}7.5 \\
\pm 1.0\end{array}$ & $\begin{array}{r}7.5 \\
\pm 0.9\end{array}$ & $\begin{array}{r}7.5 \\
\pm 0.9\end{array}$ \\
\hline Final & $\begin{array}{r}21.2 \\
\pm 4.1\end{array}$ & $\begin{array}{r}23.8 \\
+3.6\end{array}$ & $\begin{array}{r}27.6 \\
\pm 4.4\end{array}$ & $\begin{array}{r}24.0 \\
\pm 3.4\end{array}$ & $\begin{array}{r}23.0 \\
\pm 3.6\end{array}$ & $\begin{array}{r}27.0 \\
\pm 4.1\end{array}$ & $\begin{array}{r}28.5 \\
\pm 3.8\end{array}$ & $\begin{array}{r}29.2 \\
\pm 4.5\end{array}$ & $\begin{array}{r}27.5 \\
\pm 3.5\end{array}$ & $\begin{array}{r}28.9 \\
\pm 4.2\end{array}$ & $\begin{array}{r}28.9 \\
\pm 3.0\end{array}$ \\
\hline $\begin{array}{l}\text { Daily feed } \\
\text { intake } \\
(\mathrm{g} / 100 \mathrm{~g} \text { b.w. })\end{array}$ & 3.1 & 3.0 & 3.0 & 3.0 & 3.3 & 2.8 & 3.0 & 2.8 & 3.0 & 2.9 & 2.7 \\
\hline Growth rate ${ }^{* 2}(\%)$ & 183 & 217 & 268 & 220 & 207 & 260 & 280 & 289 & 267 & 285 & 285 \\
\hline $\mathrm{FE}(\%)^{* 3}$ & 72.9 & 81.7 & 89.9 & 82.5 & 73.1 & 96.6 & 93.3 & 101.6 & 88.6 & 97.4 & 103.6 \\
\hline PER & 1.8 & 1.9 & 2.1 & 2.0 & 1.4 & 1.8 & 1.7 & 1.9 & 1.6 & 1.8 & 1.9 \\
\hline $\begin{array}{l}\text { Hepatosomatic } \\
\text { index }(\%)^{* 5}\end{array}$ & $\begin{array}{r}2.1 \\
\pm 0.3 \\
\end{array}$ & $\begin{array}{r}2.7 \\
\pm 0.6 \\
\end{array}$ & $\begin{array}{r}3.5 \\
\pm 0.8 \\
\end{array}$ & $\begin{array}{r}4.0 \\
\pm 0.5 \\
\end{array}$ & $\begin{array}{r}2.2 \\
\pm 0.4 \\
\end{array}$ & $\begin{array}{r}2.5 \\
\pm 0.6 \\
\end{array}$ & $\begin{array}{r}3.0 \\
+0.6 \\
\end{array}$ & $\begin{array}{r}2.6 \\
\pm 0.5 \\
\end{array}$ & $\begin{array}{r}2.3 \\
\pm 0.3 \\
\end{array}$ & $\begin{array}{r}1.9 \\
\pm 0.3 \\
\end{array}$ & $\begin{array}{r}2.2 \\
\pm 0.3 \\
\end{array}$ \\
\hline *1 Number of fish: 30 & & & & & & & & & & & \\
\hline *2 See the footnote of & able 3. & & & & & & & & & & \\
\hline *4 Protein efficiency $r$ & & & & & & & & & & & \\
\hline *5 $\quad$ Mean $\pm S D, n=13$ & & & & & & & & & & & \\
\hline
\end{tabular}

when $15 \%$ lipid was added at a fixed protein level of $42 \%$ and n-3HUFA level of $2.2 \%$. A similar tendency was noted in fish fed $52 \%$ protein diets. A low growth rate was observed in the fish fed low lipid diets $(5 \% \mathrm{CL})$, regardless of the dietary protein levels. On the other hand, with an increase in the amount of dietary n-3HUFA, the values for both the growth rate and feed efficiency increased, recording high in diets combining $52 \% \mathrm{CP}$ with 15 and $20 \%$ lipids.
Protein efficiency ratio (PER) was almost inversely proportional to the protein content in diet (Fig. 2). However in the $52 \%$ protein diets, PER increased with an increase in the amount of dietary n-3HUFA. Hepatosomatic index was greater in fish fed the diet containing more dietary lipid, especially $20 \%$ lipid with $42 \% \mathrm{CP}$ (diet 4 ). On the other hand, low hepatosomatic indices were observed in the fish fed diets of $52 \% \mathrm{CP}$ and $20 \% \mathrm{CL}$ supplemented with 2.2 to $4.2 \% \mathrm{n}$-3HUFA. 


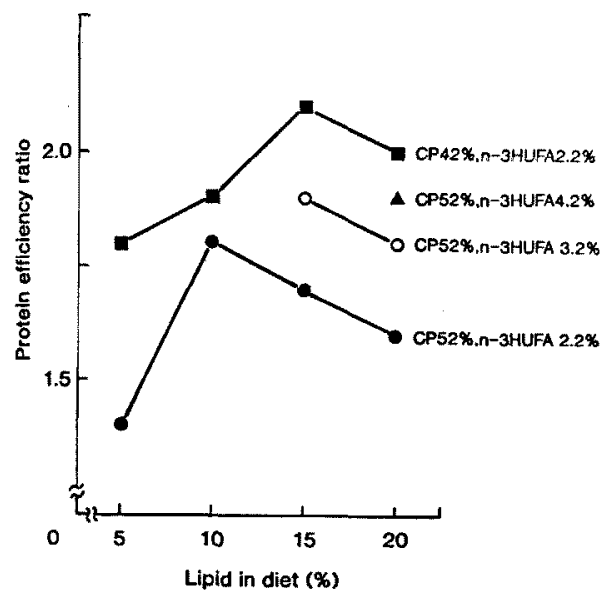

Fig. 2. Effect of dietary protein and lipid levels on protein efficiency ratio in red sea bream.

Proximate compositions of the whole body are given in Table 6 . The terminal group of fish fed each diet for 42 days showed the same ash content in their bodies, compared with the initial fish. On the contrary, dietary lipid levels reflected the lipid and moisture contents. The highest estimate of body lipid was in the fish fed diet 4 containing $42 \% \mathrm{CP}$ and $20 \% \mathrm{CL}$. Moreover, the protein content of this group of fish was lower than that of other terminal group of fish.

\section{Discussion}

Yone et $a l .^{3)}$ has already investigated the requirement of red sea bream for essential amino acids and proteins and reported that the feed efficiency for red sea bream increased linearly, until it became constant at a CP level of $55 \%$. These results are in agreement with those of this experiment. In Expt. I, the growth rate and feed efficiency increased with increasing CP content in diet, both values reaching a maximum at the $\mathrm{CP}$ level of $52 \%$. In Expt. II, assuming that the suitable CP level in diet for fingerlings of red sea bream is around $50 \%$, two series of diets were prepared with a CP level of either 42 or $52 \%$ and lipid supplements ranging between 5 and $20 \%$. The results demonstrated that the growth and feed

Table 6. Proximate composition of the whole bodies of red sea bream in Expt. II (\%)

\begin{tabular}{lrrrrrrrrrrrrr}
\hline \multicolumn{1}{c}{ Diet no. } & Initial & 1 & 2 & 3 & 4 & 5 & 6 & 7 & 8 & 9 & 10 & 11 \\
\hline CP & & 42 & 42 & 42 & 42 & 52 & 52 & 52 & 52 & 52 & 52 & 52 \\
CL & 5 & 10 & 15 & 20 & 5 & 10 & 15 & 15 & 20 & 20 & 20 \\
n-3HUFA in diet & & 1.0 & 2.2 & 2.2 & 2.2 & 1.2 & 2.2 & 2.2 & 3.2 & 2.2 & 3.2 & 4.2 \\
\hline Whole body & & & & & & & & & & & & \\
$\quad$ Crude protein & 17.6 & 18.6 & 18.2 & 18.2 & 17.6 & 18.8 & 19.2 & 18.1 & 18.4 & 18.3 & 18.3 & 18.1 \\
$\quad$ Crude lipid & 5.9 & 8.9 & 10.9 & 14.3 & 16.1 & 8.4 & 10.6 & 14.1 & 14.0 & 14.0 & 14.6 & 14.5 \\
$\quad$ Crude ash & 5.4 & 5.7 & 6.1 & 5.5 & 5.2 & 5.3 & 5.5 & 5.3 & 5.4 & 5.1 & 5.0 & 5.5 \\
$\quad$ Moisture & 72.5 & 68.7 & 68.1 & 64.5 & 64.5 & 70.0 & 66.5 & 63.9 & 64.6 & 63.9 & 62.4 & 62.4 \\
\hline
\end{tabular}

Table 7. Protein and energy required for $100 \mathrm{~g} \mathrm{b.w.} \mathrm{gain} \mathrm{and} \mathrm{daily} \mathrm{nitrogen} \mathrm{budget} \mathrm{in} \mathrm{red} \mathrm{sea} \mathrm{bream}$

\begin{tabular}{|c|c|c|c|c|c|c|c|}
\hline \multirow[b]{2}{*}{ Diet no. } & \multirow{2}{*}{$\begin{array}{c}\text { Calorie } \\
\text { in diet } \\
(\mathrm{kcal} / 100 \mathrm{~g})\end{array}$} & \multirow{2}{*}{$\begin{array}{l}\text { Total diet } \\
\text { consumed } \\
(\mathrm{g})\end{array}$} & \multicolumn{2}{|c|}{$\begin{array}{l}\text { Nutrient required } \\
\text { for } 100 \mathrm{~g} \mathrm{b.w} \text { gain }\end{array}$} & \multicolumn{2}{|c|}{ Daily intake } & \multirow{2}{*}{$\begin{array}{c}\text { Daily } \mathrm{N} \\
\text { increase } \\
\text { (mg/100 } \mathrm{g} \\
\text { b.w.) }\end{array}$} \\
\hline & & & $\begin{array}{l}\text { Protein } \\
\quad(\mathrm{g})\end{array}$ & $\begin{array}{c}\text { Energy } \\
(\mathrm{kcal})\end{array}$ & $\underset{\substack{\text { b.w.) } \\
\text { b. } / 100 \mathrm{~g}}}{\mathrm{~N}}$ & $\begin{array}{c}\text { Energy } \\
(\mathrm{kcal} / 100 \mathrm{~g} \\
\text { b.w.) }\end{array}$ & \\
\hline 1 & 277 & 568.7 & 57.0 & 383 & 207.3 & 8.7 & 69.6 \\
\hline 2 & 332 & 600.1 & 51.7 & 406 & 205.3 & 10.1 & 73.4 \\
\hline 3 & 369 & 669.4 & 47.0 & 410 & 205.0 & 11.2 & 80.3 \\
\hline 4 & 414 & 601.4 & 51.0 & 502 & 204.4 & 12.5 & 70.3 \\
\hline 5 & 315 & 634.4 & 72.2 & 431 & 279.4 & 10.4 & 74.9 \\
\hline 6 & 360 & 597.4 & 55.9 & 372 & 238.0 & 10.0 & 84.5 \\
\hline 7 & 396 & 665.9 & 57.7 & 424 & 253.8 & 11.8 & 80.6 \\
\hline 8 & 401 & 641.6 & 53.7 & 394 & 242.3 & 11.1 & 84.2 \\
\hline 9 & 430 & 679.2 & 61.1 & 485 & 261.8 & 13.5 & 79.6 \\
\hline 10 & 425 & 658.7 & 54.7 & 436 & 244.9 & 12.2 & 83.0 \\
\hline 11 & 433 & 620.4 & 51.8 & 417 & 232.2 & 11.7 & 81.8 \\
\hline
\end{tabular}


efficiency were higher for diets containing $52 \% \mathrm{CP}$, when compared with $42 \% \mathrm{CP}$ groups, irrespective of the lipid levels. Some diets containing $52 \% \mathrm{CP}$ showed more than 100\% feed efficiency. Furthermore, the daily nitrogen intake was also higher in the diet containing $52 \% \mathrm{CP}$ (Table 7). Though Expts. I and II do not include the diets containing more than $52 \% \mathrm{CP}$, it is actually difficult to increase the $\mathrm{CP}$ levels above $55 \%$, because practical feed contains fish meal as a major protein source. Therefore, why the present study did not consider CP levels above $55 \%$ is justified.

Most commercial feeds currently available for growing red sea bream have a CP level of about $45 \% .11)$ Watanabe et al. ${ }^{12}$ has reported that cuttlefish meal was better than white fish meal as a protein source for brood stock red sea bream, with the optimum CP content being around $45 \%$. Comparison of our results with those found in literature suggests that the suitable dietary CP level for fingerlings of red sea bream was $7 \%$ higher than that for adult and brood stock fish, although dietary protein is utilized for reproduction in brood fish. Thus, the fingerlings appear to require more protein than do adult fish.

As indicated in Fig. 3, when the n-3HUFA content was constant at $1.2 \%$ or $2.2 \%$, addition of lipid to a diet containing $52 \% \mathrm{CP}$ increased the dietary energy (DE) and the growth rate which reached a maximum at around $400 \mathrm{kcal} / 100 \mathrm{~g}$ diet $(15 \% \mathrm{CL})$. The growth rate however, was lowered when lipid was added up to $430 \mathrm{kcal} / 100 \mathrm{~g}$ diet. For diets containing $42 \% \mathrm{CP}$, on the other hand, the highest growth rate was achieved at $370 \mathrm{kcal} / 100 \mathrm{~g}$ diet $(15 \% \mathrm{CL})$, but was reduced when the DE was increased to $410 \mathrm{kcal} / 100 \mathrm{~g}$ diet $(20 \% \mathrm{CL})$. Yong et al. ${ }^{33)}$ have reported that the daily feed consumption of Tilapia depends on the $\mathrm{DE}$ content in the diet, the ingestion rate immediately decreasing with an increase of the DE content, leading to a lower growth rate. In our study, the growth rate was found to decrease in diets with $\mathrm{DE}$ at more than $400 \mathrm{kcal} / 100 \mathrm{~g}$, regardless of the protein levels. Nevertheless, the daily feed consumption of these diets was virtually the same as that in other diets and furthermore, the daily energy intake in these diets was larger than in the others (Table 7), indicating that the decrease in growth rate in these diets was not the result of a decrease in daily feed consumption. An analysis suggested that when the n-3HUFA content in diet is kept constant at $2.2 \%$, the addition of $20 \%$ lipid leads to a de-

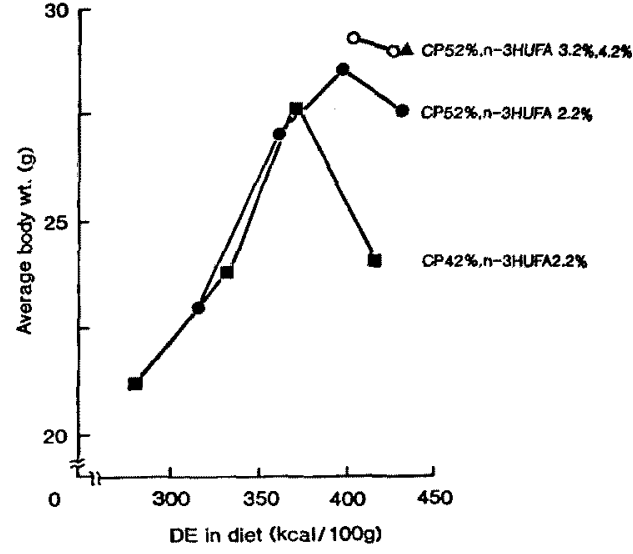

Fig. 3. Relationship between digestible energy (DE) in diet and growth of red sea bream.

ficiency of n-3HUFA, an essential fatty acid (EFA). In fact, an increase in the n-3HUFA content permits an increase in growth rate, and it can be concluded that an increase in the requirement for n-3HUFA is caused by the addition of $20 \%$ lipid (descussed in detail later).

These results, coupled with the fact that diets containing $15 \% \mathrm{CL}$ produced a higher growth rate and feed efficiency regardless of the protein levels, suggest that the suitable CL level in diet for fingerlings of red sea bream is around $15 \%$ when the n-3HUFA is kept constant at $2.2 \%$.

In the diets incorporating either 15 or $20 \% \mathrm{CL}$ with a varying n-3HUFA content in the range from 3.2 to $4.2 \%$, the growth rate, the feed efficiency and PER were higher than in the diets containing the same CL contents but with $2.2 \%$ n-3HUFA (Figs. 1 and 2). These results suggest that the growth rate of red sea bream depends on the content of n-3HUFA and the n-3HUFA requirement increase with the $\mathrm{CL}$ level. For the rainbow trout, the amount of linolenic acid, an EFA, required to achieve the maximum growth is known to increase with increasing CL level of diet, ${ }^{16)}$ but no reports have appeared for these relations for red sea bream. It seems inappropriate to discuss the optimum CL level in diet for fingerlings of red sea bream only in terms of the lipid levels. Further investigations are necessary to identify the optimum n-3HUFA content at different CL levels.

Thus, this result indicates that suitable CP and CL levels in the diet for red sea bream fingerlings may be around $52 \%$ and $15 \%$, respectively, but further experiments are being performed to study 
the optimum CL content in relation to the $\mathrm{n}$ 3HUFA content in diet. These results will be presented shortly.

\section{Acknowledgements}

The authors express here our sincere thanks to Mr. Toshihisa Arakawa, Nagasaki Prefectural Institute of Fisheries, and Mr. Ichiro Kobayashi, Tokyo University of Fisheries, for their techical assistance. The present work was supported in part by a research fund from Marino-Forum 21 and Riken Vitamin Co. Ltd.

\section{References}

1) Y. Yone and M. Fujii: Nippon Suisan Gakkaishi, 41, 73-77 (1975).

2) Y. Yone: Rep. Fish. Res. Lab. Kyushu Univ., No. 3, 87-101 (1976).

3) Y. Yone, M. Furuichi, and S. Sakamoto: Rep, Fish. Res. Lab. Kyushu Univ., No. 1, 49-60 (1971).

4) C. Ogino, L. Takeuchi, H. Takeda, and T. Watanabe: Nippon Suisan Gakkaishi, 45, 1527-1532 (1979).
5) C. Ogino and G.-Y. Yang: Nippon Suisan Gakkaishi, 44, 1015-1018 (1978).

6) J. Folch, M. Lee, and G. H. S. Stanley: J. Biol. Chem., 226, 497-507 (1957).

7) S. Fukui: "Determination of Reducing Sugar", The University of Tokyo Press, Tokyo, 1974, pp. 10-12.

8) T. Watanabe, T. Takeuchi, T. Arakawa, K. Imaizumi, S. Sekiya, and C. Kitajima: Nippon Suisan Gakkaishi, 55, 1111-1118 (1989).

9) S. Shimeno, H. Hosokawa, M. Takeda, and H. Kajiyama: Nippon Suisan Gakkaishi, 46, 10831087 (1980).

10) T. Watanabe, T. Takeuchi, S. Satoh, T. Ida, and M. Yaguchi: Nippon Suisan Gakkaishi, 53, 1413-1423 (1987).

11) Y, Ohshima: "Senkai Yoshoku" (ed. by Resources Association), Taisei, Tokyo, 1986, pp. 634-648.

12) T. Watanabe, A. Ito, C. Kitajima, and S. Fujita: Nippon Suisan Gakkaishi, 50, 1015-1022 (1984).

13) W.-Y. Yong, T. Takeuchi, and T. Watanabe: Nippon Suisan Gakkaishi, 55, 869-874 (1989).

14) T. Takeuchi and T. Watanabe: Nippon Suisan Gakkaishi, 43, 893-898 (1977). 